\title{
Educating for (whose) success? Schooling in an age of neoliberalism.
}

How dare you in all your ways seek to judge us,

Imprison us in our own minds with ghostly figures and cold mirrors.... (Allen ${ }^{1}$ )

In Western nations, the social and economic changes of the last thirty years have facilitated a reorientation of the focus of educational institutions. Global capitalism has placed education at the forefront of national competitiveness and governments have responded with education policies primarily designed to serve the needs of the market. Such neoliberal economic imperatives have been supported by a variety of neoconservative social forces calling for schools to become sites of cultural and moral restoration. This paper draws upon current theoretical debates about the consequences of such changes and employs ethnographic data from a small qualitative study ${ }^{2}$ of Australian youth to argue the case for a more democratic and student-centred approach to educational reform. It contends that in the interests of all young people, it is time for schools to resist systemic impulses to make them producers of human capital and claim their role as transformative institutions of human possibility.

\section{Introduction}

Neoliberalism encompasses traditional liberal principles of right-wing economics coupled with varying degrees of conservative ideologies that may include national, traditional or religious impulses (Apple 2006). While classical liberalism promises individual freedom from state controls, neoliberal impulses favour state powers that actively shape the kinds of individuals who will help to optimize the economy (Olssen et al. 2004). In recent times, Australia and other developed nations have increasingly adopted schooling reforms that echo their neoliberal agendas within broader areas of social policy (Luke 2006). As a consequence, the ethos of the free market has gradually colonized teaching and learning and commodified its participants and outcomes (Weis et al. 2006, 246-47). 
It is not my intention to document individual national education reforms. Such global shifts have been thoroughly explored by others (see for example, Apple 2006, 2007; Apple et al. 2005; Ball, 1994, 1998; Connell et al. 2007; Sadovnik 2007; Scott \& Freeman-Moir 2007). Rather, this paper challenges assumptions that the primary role of teachers is to shape human capital (Apple 2007) for the private sector. To support my theoretical arguments, I have included relevant data from a small qualitative study I conducted with a group of Australian secondary students. This research project involved an in-depth exploration of contemporary youthful transitions and identity construction. The study went beyond the focus of this paper, which does not presume to reflect the entirety of the original research. The topic explored in this paper is but one of the many issues that emerged during my two years of data gathering.

As I learnt more about my participants, one of the fascinating elements that emerged was the way in which those who had been constructed as either 'trouble' or 'failures' seemed to be engaging in their own learning within their peer group. Twentytwo of the thirty-two students ${ }^{3}$ who took part in the research were frequently involved in varying levels of conflict with school authorities. These incidents ranged from minor infractions relating to appearance or lateness to class to exclusions from school because of the use of offensive language. For this group there seemed to be a level of persistent boredom and because they were students of moderate to high ability ${ }^{4}$, they would sometimes turn their wit against their teachers in an effort to disrupt the flow of lessons and inject the topics that interested them. Conversations with them about such incidents revealed resentment towards homework and testing regimes that rewarded, as they saw it, 'performing for the teacher'. As a teacher myself, I was all too aware of the increasing systemic requirements relating to performativity and accountability. As the school publicity officer I knew that government schools were being forced to compete for students in an educational marketplace increasingly shaped by managerial discourses 
more consistent with the world of free enterprise. The fact that these intelligent young people were not being served by this system was troubling - and challenging - because, after all, $I$ was part of that system. In my youth, somewhat idealistically, I had chosen the teaching profession in order to 'make a difference' and perhaps with the passing of the years I had forgotten that. A re-engagement with critical theory at the time of research clarified my feelings of discomfort and reaffirmed my conviction that I had not become a teacher in order to shape human capital.

This article proceeds through four stages. It begins by establishing the theoretical background to the research and then provides an overview of my research context and orientation. This is followed by a discussion of the tensions between neoliberalism and transformative education. Prior to my concluding remarks, the fourth section invites reflection upon the capacity of students to be partners in educational processes rather than products that have been shaped to serve the needs of external interests. The voices of my students are heard throughout this paper and join with mine in contesting the limitations and inequities of current directions in educational content and management.

\section{Theoretical context}

For several decades, conservative forces in developed nations have been reshaping social institutions and practices around economic, rather than social democratic, imperatives (Weis et al. 2006). In what he calls processes of conservative modernization critical educator Michael Apple (2006) argues that schools have been colonized by a market ethos of 'what counts' as important knowledge:

We have been told to free our schools by placing them into the competitive market, restore our traditional common culture and stress discipline and character ... (5).

The nexus between knowledge, cultural capital and power has been explored by many theorists (Bourdieu 1984; Connell 1993; Foucault 1977a, 1980; Apple 2006, 2004). It 
explains why schools continue to reproduce social inequality and suppress alternative knowledge frameworks. Scholastic 'success' is closely connected to ideological projects of identity construction. Increasingly, concepts of 'citizenship' are being shaped by neoliberal discourses of individual rather than collective responsibility. Instead of facilitating the social 'good' of education, schools have become places that add capital value to youth (White and Wyn 2008). Potentially, students are the "docile bodies (Foucault 1977a) of market forces. However, the will to self-constitute and contest ideological constructions and discursive practices has been used by numerous subaltern groups to resist oppression (Apple and Buras 2006). In applying the term 'subaltern' to school students, I wish to affirm their positional powerlessness within current educational struggles over curriculum and pedagogy. If their voices are heard at all, they are regarded as marginal and uninformed. Consequently their responses to 'official knowledge' may manifest in a variety of behaviours such as disengagement, class disruption or the search for a more personally relevant education outside of school. However, personal resistance in the schooling context is problematic for youth.

To challenge teacher authority implicitly or explicitly puts the student at risk of being labelled a troublemaker as illustrated in the following editorial, Curbing the Hooligans (The Sunday Mail March 9 1997):

The new drive to deal with disruptive students is to be welcomed. Discipline in schools has been a sore point for years; especially since the cane was abolished in 1993 ... we cannot allow the relatively few unruly students to disrupt the studies of earnest students or to prevent teachers from doing their jobs ...

Such media commentaries oversimplify the complexities of student engagement by creating binaries of 'good' and 'bad' youth. Along with greater legislative powers in respect to the young (Davis, 1997), the years $1996 / 1997^{5}$ heralded promises of increased official 'action' in respect to school discipline in Australian schools. In the State of Queensland ${ }^{6}$ school based police were stationed at some sites and the power of 
principals to suspend and expell students was greatly enhanced (Education, General Provisions, Amendment Act 1996).

As a practising teacher in Queensland schools in the late 1990s, I began to have doubts about the ideologies driving Australian youth and education policies. Such reservations shaped the focus of my research. I wanted to explore contemporary experiences of youth within the context of a neoliberal, globalising, postmodern 'world' and I wanted to interrogate the assumptions that constructed non-compliant students as hooligans - as youth in need of punishment and/or counselling and remediation until they accepted the status quo of the 'manner and matter' of an education increasingly being shaped by a neoliberal ethos.

\section{Research context}

Hoffman $^{7}$ State High School is situated in a major metropolitan area of Australia's subtropical state of Queensland. Largely middle class and multicultural, the school lies very close to a major university and draws a significant number of its students from the families who staff it. This has ensured a continuing thread of progressiveness that led to the demise of school uniforms in the 1970s and an ethos founded upon traditions of a socially aware student body. However, by the late 1990s, the political climate had changed, and as elsewhere, Australian education systems were being shaped by neoliberal beliefs that demanded greater competitiveness from government schools. In practice this led to calls for greater student conformity amid discourses of managerial efficiency, 'standards' and teacher accountability. Consistent with this trend, a conservative administration at Hoffman State High was trying to direct student energies towards projects that were socially 'acceptable' in terms of the image of the school. For example, one of my students received significant public praise from the school for his promotion of multiculturalism whilst another, equally able student but one committed to 
issues such as combating homophobia, was unable to gain sufficient support from the school to gain entry into a study abroad program.

The selection of research participants was shaped by their availability. I was a practising secondary teacher at the time of my research and I issued invitations to students in my Year 11 Modern History and English classes. In order to avoid stereotyping of youth I decided to develop my project around individual case studies (Denzin \& Lincoln, 1994). Having obtained ethical clearance and permission from school administrators, I approached students and their parents and explained the rationale for my research. Significantly, I received messages of support and encouragement from the parents whose children agreed to participate. The thirty-two students who volunteered for my study were largely 'typical' Hoffman High students in terms of their varying levels of adherence to alternative perspectives. The sub-group of twenty-two from whom I derived most data were distinctive by the particular closeness of their relationships, their propensity for student activism and the ways in which they supported each other intellectually ${ }^{8}$.

\section{Radical spaces: my part in the process}

My socio-political orientation is best described as being informed by a mix of feminist and leftist politics that aspires to achieve social justice. My teaching philosophy has been influenced by the type of critical pedagogy advocated by the likes of Paulo Freire (1970), and Henry Giroux (1981). I believe that education is a 'gatekeeper' to the paths of either social reproduction or social transformation, but I also recognize, as does Freire (1976) that educational change is inextricably bound up with social changes that are shaped by many powerful external forces. However to do nothing is to side with the powerful. In an interview with Donald Macedo in 1996, Freire maintains the position that "if education cannot do everything, it can achieve some things ... one of our 
challenges as educators is to discover what is historically possible in the sense of contributing to the transformation of the world (Freire 1996, 222). Just what is "historically possible" is a challenge for each and every teacher.

My relationship with participants was more complex than that of researcher and subjects. I was also their teacher, mentor and confidante - not friend. This is an important distinction as they did not treat me as 'one of their own' but rather, as a 'spectator' to 'their worlds' and as someone to whom they could come for advice and support. The reflexivity among the group about research processes was quite fascinating as illustrated by this comment from Paul:

Has it ever occurred to you that perhaps that we ... have altered our identities to your desired outcome? Or perhaps that the mere act of studying us has forced us to adapt our outward personae?

Thus, in the construction of their narratives I was both a participant and a facilitator who encouraged her students to become "self-directed human beings capable of producing their own knowledge” (Kincheloe 2004, 17). In hindsight, this was possibly a politically naive decision. The close researcher/participant relationship needed for effective qualitative research did not sit comfortably with the traditional power relations at the school. Staff and administration objected to participants' use of my first name and my researcher interest in participants' activities was constructed as facilitating their 'troublemaking'.

However, despite the personal and professional discomfort I endured for the two years of data collection, I still believe that teachers need to become advocates for students. Within the 'audit society' (Power 1999) of neoliberal educational agendas there is little room for student autonomy. My experiences at Hoffman State High convinced me that teachers, too, are constrained and, as accountability rises; they will be forced into greater systemic compliance. As Luke (2006) notes there has been, 
... a retrograde recommodification of knowledge, as systems and teachers increasingly turn or return to an industrial model of teaching, with packages, tests, and standardized pedagogic sequences seen as enabling both compliance to new criteria for performativity ... and ... simple occupational survival (123).

Standardisation of 'what counts' as important knowledge and decreasing teacher autonomy coupled with the possibility of performance-based pay narrows the educational vision and thus limits the possibilities for engaging students in personally meaningful modes of learning.

\section{Sharing stories}

For the purposes of this paper, I am drawing upon data generated by some of the students who experienced varying amounts of conflict ${ }^{9}$ with schooling authorities. I have not sufficient space to adequately represent all of these young people so I have selected representative samples ${ }^{10}$ of prose and poetry ${ }^{11}$ that demonstrate some of the conceptual themes that seemed to matter to them. The ten students who experienced negligible conflict consistently conformed to the demands of the school and were quietly interested, minor participants. From them I gathered data ${ }^{12}$ relevant to broader aspects of my project, such as youthful identity construction.

In order to avoid popular assumptions about the universality of the youth experience, I employed a feminist and postcolonial methodology that recognizes the subjective nature of all research and foregrounds the legitimacy of narrative and dialogic meaning making in the field (Hall 1996; hooks 1996; Lather 1991a; Lather 1991b; Reinharz 1992). Data was generated from interviews, emails, group discussions and a variety of creative texts. Drawing on the ideas of Russian intellectual, Mikhail Bakhtin (Clark and Holquist 1984) I engaged my students in dialogic narratives in collaborative exercises of 'meaning-making'. According to Bakhtin, dialogue comprises 'utterances' which he defines as the means by which we navigate our journeys through the twin forces of difference and unity/sameness (Clark and Holquist 
1984). . Such a framework was important because, as a teacher, I had to establish a 'thirdspace' (Soja 1996) that would facilitate the disruption of the teacher/student binary and position me simultaneously as 'insider', 'outsider', both and neither - a space not easy to occupy and full of challenging and ambiguous moments that often positioned me as an 'outsider' within the hierarchical power relations of the school.

Whilst parents remained supportive of my work, relations with the school principal became increasingly strained to the effect that at the end of the two years, I was transferred to a neighbouring school. This was met with protests from parents and students who started a petition to retain my services at the school. Their efforts were not successful as my transfer was deemed to be a normal part of district staffing changes. However, I believe that the support from these stakeholders validated my work and supported my call for the need for greater student advocacy from teachers.

The data shows my students exploring the ideological possibilities that stood in opposition to the official curriculum and systemic impulses to dampen the critical sensibility evident in the following extracts:

(From Jack’s ${ }^{13}$ notebook)

From the beginning it seemed a tragedy not to live your life to the full potential. Why, then do people work in the city, behind a desk, pushing papers while waiting for the next cigarette break? Money is a god. ... Words are a god. That's why we get marked. What does this marking prove? That we can spell? Why are we marked on spelling when spelling is constantly changing? If Shakespeare were alive today he'd fail English. Who spells shop, shoppe? Spelling is a triviality. Thesaurus the saurus they saw us not doing as we were told, so the saurus thought us hooligans :-

Cornell: It's still incredibly arrogant and dogmatic, you know, to think that you can justify ....imposing your will on someone - You know? That your rationale is correct.....

Traditionally, students have little control over their schooling experiences (White and Wyn 2008). To confront this situation, requires a radical repositioning of educators so that, as Connell (1993) argues, we may challenge hegemony:

By adopting the "standpoints" of the "socially subordinate ... (and) ... think(ing) through economic issues from the standpoint of the poor, not rich ... think(ing) through gender arrangements from the standpoint of women ... think(ing) through race ... relations from the standpoint of indigenous people ...” (43). 
It is also necessary to "think through" schooling from the standpoint of young people who are mostly "educationally subordinate”. In fact, we need to encourage dialogues that acknowledge the validity of their perspectives.

\section{The data}

The data used in this paper makes no claims for universality of meaning. Derived from individual case studies, its inclusion is an invitation to reflect upon popular assumptions about young people and the ways they are educated, that in the words of critical educator peter McLaren (2006) "harmonize the purpose and function of schooling with the current reign of capital ... (and places) ... critical pedagogy under intense scrutiny” (23). Conversations with participants provided consistent evidence of a concern about the type of education they were receiving and a rejection of a life geared to endless consumption with "the market uber alles ... shopping malls ... (and) ... an atomized society of disengaged individuals” (McChesney 1999, 11). A critical social awareness surfaced in many of our dialogues, as exemplified in the following extract:

Simone: And it's so ridiculous... The way most people live their lives in affluent countries. Shopping malls ... it's just ridiculous! It's a structured reality I don't think that what we are getting is education except maybe learning from what we don't want it to be. I think education is how you think. ... which is probably the most important.... school is so impossible, with stress and ...the authority structures in school ... And there are so many more jobs and more ways of living than just having a career in an office .... like studying and learning and travelling and just living your life the way you want to..

Unfortunately such views are usually disregarded as the existential angst of young people (McGregor 2000). Although my research participants demonstrated significant intellectual engagement with learning their personally defined unofficial curriculum of counter-cultural texts and behaviours subsequently constructed them as disengaged troublemakers. As Weis et al. (2006) note,

Neoliberals are critical of existing definitions of knowledge, especially that knowledge that has no connections to what are seen as economic goals and needs. They want creative and enterprising (but still obedient) workers. Flexibility and obedience go hand in hand (247). 
Those who support a deficit model of youth may construct my student participants as latter-day self-obsessed Holden Caulfields ${ }^{14}$ obtusely defying the authority of adults. However, I would argue that there is an increasing body of respected critical theory (as cited in this paper) that also queries the validity of education systems that focus on the production of human capital rather than human possibility. In using this term, I am advocating student-centred, democratic systems that educate in the interests of the individual. Clearly, such an approach may well produce the 'human capital' sought by industry, but it is not the priority.

\section{The purpose of schooling: human capital vs personal agency}

The thing that is non-negotiable, is freedom ... (Allen)

Today, human resource development is regarded as vital to achieving a competitive global edge. Over time, corporate discourses of accountability, marketisation and managerialism (Ranson 2007) have become normalised master narratives - regimes of truth (Foucault 1980) and part of a 'common-sense' governance broadly endorsed by most Australian politicians. Those who suggest alternative models are silenced by the sheer weight of neoliberal rhetoric emanating from both sides of the political spectrum. The lack of public debate has allowed for a neoliberal appropriation of Human Capital Theory (HCT) (Marginson 1993) that commodifies our young people under the guise of preparing them for future employment. HCT "represents human beings as the passive playthings of external forces ... (in which) ... investment in individuals' education will solve all the structural problems of the economy” (Olssen et al. 2004, 150). Thus, the job of the state is to deliver human capital as an economic return from educational investment, "the optimization of the global relationship between input and output" (Lyotard 1984, 11). The difference between the 1960s' model of HCT and a contemporary neoliberal version is that the pay-off now resides in the economic benefits 
that flow from investment in education rather than in any moral, social or ethical contributions to the 'public good' (Marginson 1993).

To my knowledge, my research participants were unaware of theories pertaining to a neoliberal reframing of education systems. However, it is clear from the data that they reacted to an increasing emphasis upon 'functionality' in their schooling and a tightening of discipline in ever-expanding modes of accountability and documentation of student 'mis/behaviours'

\section{Dissenting voices}

My research group frequently voiced their doubts about the materialistic goals promised by their education as exemplified in the following texts:

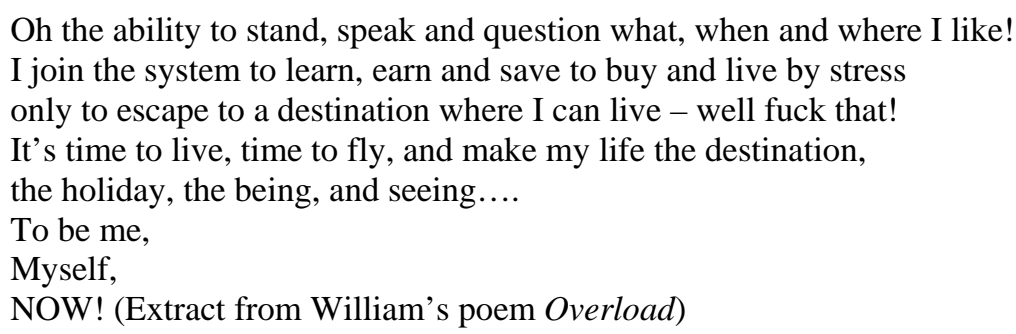

We still keep running to our jobs, home, job, pub, home, groceries, nappies, power bills, telephone bills, credit card bills, duck bills for all I care! Pension then death. "Where did all the time go?” It went when you were glancing at your watch waiting for the bus which is already late...... (essay extract - Jack).

Such narratives demonstrate the developing 'critical subjectivities' of my students and their interrogation of social and cultural assumptions about the purpose of education, particularly its role in the production of 'human capital' for the kind of existence imagined by Jack in his essay. For these young people, the 'project of the self' became the vehicle by which they exercised agency and began to define the types of knowledge that counted for them. Neal, for example, explored these themes in our emails:

Neal: What is the self? I am never sure if it is my self which is showing or an environmental me. Often I feel disgusted with myself. It is different every time I look at it. Like trying to describe a sea whose face constantly changes with the movement of the wind and of the moon..... I don't know who I am..... 
The data reveals that within this group of young people were creative, critical thinkers who embraced diversity and intellectual work. Their conflicts with school authorities were not the consequences of violent and abusive acts but the result of varying levels of non-compliance coupled with bold assertions of their right to ' be free'. However, I would argue that conflict is a necessary part of social justice. Denying students opportunities to challenge the hegemonic assumptions of social status and age inherent in school rules also teaches them to accept similar hierarchies in society as a whole (Apple 2004, 92).

\section{The politics of identity}

Control is a god. Badges on our shirts. Regimented DNA samples of every student instantly identifiable by what they're wearing. Categorising is the son of control ...

(Jack)

The acts of resistance engendered by research participants were infused with spontaneous playfulness and linked to their sense of self and meaning. Dancing to the music of Thelonious Monk on the green grass of the school quadrangle, they removed their shoes (forbidden at school) and played like carefree children in the sunshine. They were loud and joyous in their defiance of the many petty rules that control the lives of school children - rules about tidy hair and shoes and decorum. Their antics resonate with Mikhail Bakhtin’s (1984) concept of carnival which challenges the hegemony of the dominant order by reversing symbolic values. That which is 'unspoken' is uttered and the 'high' becomes 'low' and vice versa. It is based on parody, profanities and games. For my students, carnival exploded impulsively: Allen in his party hat during an important external examination; games, laughter, music and swearing - the word 'fuck' being the ultimate weapon in the reversal of the dictated order of things. Consider the tone of the following email from Neal. For a seventeen year old boy, it is breathtaking in intellectual scope and passion, yet if it had surfaced at school he would have been 'disciplined', possibly even suspended as had happened to Jack - (“You don't want to be 
really offensive...it's necessary sometimes to have a swear word ...”) - who had dared to

swear in some of his school essays:

Neal: French 1950s 'avant garde' were lousy fucking cunts who fucked up the french literature of the first half of this century. They were shallow bastards who played shallow games with great writers - Celine's reputation was destroyed by public attacks by sartre even .. though he's one million times the better writer. Proust was disgarded as being a member of the idle rich. Just watch a french new wave film or read Sartre to see how full of phoniness and bullshit it all is. It is all just pretentions towards deep + meaningful intellectualism by supposed revolutionaries who were just middle-class shits who couldn't write. Incidentally just finished a volume of Sartre's short stories - noticed some faults and mediocrity in his writing ... hmmm..

Because of prevailing tendencies to treat senior high school students like children most school authorities find it difficult to get past the surface realities of adolescent swearing and engage with the intellect of their students (McGregor 2000). As noted by Gilles Deleuze in conversation with Michel Foucault, "children are treated like prisoners. Children are submitted to an infantilization that is alien to them” (Foucault 1977b, 210).

As a result of their own literary journeys and on-line adventures, my students appropriated the imaginaire (Appadurai 1996) of the resistant thinkers of European Romanticism and the music and counterculture of America in the 1950s and 1960s. They used it to transform their social practices, sites of agency and identity construction. The result was a pastiche of 1960s' counter-cultural philosophies hybridised with Nineteenth century European Romanticism and dashes of the French Absurd: Nietzsche in beads, smoking a joint and admiring daffodils by the side of the road, whilst Waiting for Godot ${ }^{15}$ and hitching a ride to Woodstock - a fascinating choice of symbolic communities for Australian teenagers at the dawn of the twenty-first century.

How can we change the world if we don't change ourselves first? (Cornell)

In a paper of this length, it is not possible to explore all of the data from my project. For instance, the dynamics of gender (Mills 2000) presented some interesting tensions. The boys embraced traditionally feminised subjects (McGregor and Mills 2006) such as 
poetry, music and literature and centred their resistance within their subjectivities. However, practical projects such as 'Body Rights Week', conceived as a way to enhance social and cultural inclusivity, largely became the responsibility of the girls in my research group. Thus, for the girls, activism involved practising their beliefs in ways that they believed contributed to the 'common good', whilst the boys were more interested in challenging personal educational constraints as evident in the following correspondence:

Neal: At the moment I am dealing with the mediocrity of Mr X in doing my IPT assignment and find it very hard to be patient. He is one of those people that in reality knows nothing but masks it by intimidating people...

As part of a school marketing strategy of attempting to forge links with the local university, another of the students, Paul, gained entry to a first year history course. The experience proved to be an exciting revelation:

Uni today was fucking brilliant. It was all the things school SHOULD be. I got to think, think, discuss, listen to people who generally knew what they were talking about, think and be overwhelmed by the general authority the lecturer seemed to have .... School was hell..... Long live self. (Email)

The 'self' and the desire for a more personally stimulating education dominated their musings.

As a deep vein of Romanticism emerged during the second year of the research, the students intellectualized their resistance in a variety of personal texts that echoed the preoccupations of their literary heroes, particularly the Beats. They became 'travellers on a road' along which they sought creative and personal freedom even as they pondered the futility of their quest as illustrated in Neal's poem, Bohemian Dreams:

Is this how you imagined it Neal Cassidy?

Dead in deepest cold.

What of you Bill Burroughs -

How was Tangiers?

And you Allen Ginsberg,

hippy culture queen -

Whatever happened to

your sweet bohemian dreams?

Perhaps this is

how it was meant to be.

Freedom is

after all 
only an illusion.

These students became critical, self-educated consumers of literature that extended far beyond the official reading list. As the children of middle class families, many of them had travelled overseas and in the following poetic email, Neal combines his experiences of travel and with an impressive intellectual engagement with English literature:

In Vietnam I saw:

The England of Dickens (artful dodgers, dark brick kilns)

The America of Kerouac (hobos + lonesome travellers)

The America of Steinbeck (okies + country folk)

The America of Upton Sinclair (people sleeping on streets in newspapers)

The Darkness of Conrad on the Laos/Vietnam border

The Middle Ages of Hesse (idyllic countryside, village girls)

The High Mountains of Buddhism (tall mountains descending to green valleys)

I saw the bullshit of capitalism (coke + chewing gum everywhere)

I saw water buffalo wallowing in rice paddies in the land in the middle of the airport

I saw three year olds get down on their knees and beg for money

I saw children smiling because people had been kind to them

In Europe you see.

AMERICA......

Unlike quietly despairing peers, such as Neal, Jack met life with optimism. I have enduring images of Jack and sunshine on grassy spaces at the school - arms gesticulating as he held court amid a group of friends. Or - Jack becoming King Lear in the classroom - Jack - laughing playfully, ironically, scornfully at those 'lesser mortals' (usually teachers) who attempted to contain him. His writing at that time was a mixture of Romantic and philosophical reflections:

Man's desire for knowledge creates falsehoods, trivialities, irreverence. Man's fear of death creates gods. The car is a god, TV is a god, sweet fuck is a god. The fear that envelopes us all is two-fold: Fear of solitude, loneliness and death - sweet life-taking death. Life is a lifetime, death an instant, yet we seem to strangely focus on the most insignificant moment of our lives.

Death creeps slowly in the night clutching a dagger that holds the key to life. Maybe death is a god. Plutonium is a god, therefore Australia is the mother of a god. If you have plutonium on your side, then no-one shall stand against you. We are all humans trapped in a shell of plutonium and petroleum, electricity and tax returns, fried eggs and cold coffee. Fuck that! I'm not in for your gods! I'm not associating myself with your trivialities, your lime green cargo peddle pushers! I'm making myself a god!

Many developmental professionals are dismissive of such adolescent desires for 'freedom', yet recent research questions the legitimacy of this view:

The distinction between adolescence and adulthood is a matter of cultural expectations rather than a matter of intrinsic psychological characteristics (Moshman 1999, 118). 
Nevertheless, behaviour management policies in schools still tend to focus on individual deficit, casting 'rebellious' students as 'the problem' rather than seeing them as bitplayers in a much larger sociological contest.

\section{Conclusion}

No more sitting around wishing for a revolution, you have to be the revolution...

(Simone)

In this paper I have explored a number of ideas that are at war with each other in fields of educational reform. Neoliberal and neoconservative forces see education as the producer of obedient, and "moral” human capital in opposition to critical educators who regard it as the facilitator of human possibility. My personal positioning on this issue is summed up by Marxist educational theorist Glenn Rikowski (2006) when he observes, that "the concept of 'human capital' expresses something quite horrific; the human as capital!” (258). The current direction of global educational reforms that privilege standards, accountability, competition and quantifiable outcomes is of great concern to me and to other educators who believe in a critical pedagogy with the capacity to help students deconstruct the world around them and negotiate a just place within it. I believe it is vital that teachers become critical practitioners who reclaim their agency in the classroom and challenge the increasingly popular top-down approaches to curricular content.

To illustrate my points I have drawn upon some of the creative and conversational texts of a group of students whose growing critical competency and assertive subjectivities combined to challenge the regulatory powers of their own school. They did not aspire to drop out. They wanted lives that encompassed more than economic goals:

You go to school so you can go to uni so you can earn money so you can buy a house, have kids and live a stressed out life, and then you go away on holidays... Yet you can live your life as a holiday...

Make your vocation your vacation! (William) 
Their approach to social reform stemmed directly from their focus on self, identity and personal empowerment:

You can't change the world ....If you make decisions on a huge scale, it's not going to work you know. You can't change the world but you can change your little world. I used to sit around wishing things would be different but you have shown us that to change anything you have to live that change: be that change: create the change ... (Simone)

Clearly such sentiments could be criticised as the mere idealism of youth were it not for the fact that these are timeless human aspirations that can be found in the writings of many adult social reformers.

There is a wealth of critical theory, much of which I have cited in this paper, that echoes my concerns with the current directions of educational reform. Whilst it is true that training for livelihood is a vitally necessary part of education, it should not the whole and it should certainly not serve the interests of global capitalism. Such an education dehumanises young people, quantifies their 'value' in economic terms and ignores the multi-dimensionality of their needs as complex social and emotional, developing human beings who, in partnership with critically aware educators, have the capacity to be agents of their own destiny. 


\section{Notes}

\footnotetext{
${ }^{1}$ Student participant. All names have been changed.

${ }^{2}$ My doctoral research.

${ }^{3}$ Twenty-one boys and eleven girls aged 16-17 drawn from my English and history classes.

${ }^{4}$ According to school records.

${ }^{5}$ The year in which I commenced my doctoral research

${ }^{6}$ The State in which the research was conducted.

${ }^{7}$ Pseudonym

${ }^{8}$ None of the students received the best possible school exit score of an Overall Position (OP) ranking of 1. However, one boy received the lowest possible ranking of 25. Of the others, results were scatted along the 1-25 continuum. Post-school destinations included: universities, the workforce, a family-based communal farm and volunteer environmental work. Many remained active in student politics. ${ }^{9} 22$ of the 32 students.

${ }^{10}$ The work of seven students has been cited directly with many indirect references to other students.

${ }^{11}$ Original syntax and spelling retained throughout.

${ }^{12}$ Not used in this paper.

${ }^{13}$ Many of the students carried notebooks in which they wrote down their thoughts and poetry.

${ }^{14}$ Main character from Catcher in the Rye by J.D. Salinger.

${ }^{15}$ Absurdist play by Samuel Beckett.
} 


\section{Reference List}

Appadurai, A. 1996. Modernity at large: cultural dimensions of globalization. Minneapolis: University of Minnesota Press.

Apple, M. 2004. Ideology and Curriculum. $3^{\text {rd }}$ ed. New York and London: RoutledgeFalmer.

Apple, M., Kenway, J. and Singh, M. eds. 2005. Globalizing Education. New York: Peter Lang.

Apple, M. 2006. Educating the "Right" Way. $2^{\text {nd }}$ ed. New York and London: RoutledgeFalmer.

Apple, M. 2007. Whose Markets, Whose Knowledge. In Sociology of Education: A Critical Reader, ed. A. R. Sadovnik, 177-196. New York and London: Routledge.

Apple, M. and Buras, K. L. eds. 2006. The Subaltern Speak: Curriculum, Power, and Educational Struggles. London and New York: Routledge.

Bakhtin, M. 1984. Rabelais and his World. Bloomington: Indiana University Press.

Ball, S.J. 1994. Education Reform. A Critical and Post-structural Approach. Buckingham: Open University Press. 1998. Big policies, small world: an introduction to international perspectives in educational policy. Comparative Education 34 no. 2: 119-30.

Bourdieu, P. 1984. Distinction, London: Routledge.

Clark, K. and Holquist, M. 1984. Mikhail Bakhtin. Massachusetts: Harvard University Press.

Connell, R. W. 1993. School and social justice. Toronto: Our Schools/Our Selves

Connell, R., Campbell, C., Vickers, M., Welch, A., Foley, D. and Bagnall, N. 2007. Education, Change and Society. Oxford and New York: Oxford University Press.

Curbing the Hooligans. 1997. The Sunday Mail, March 9. Editorial. Qld Newspapers Ltd.

Davis, M. 1997. Gangland: Cultural Elites and the New Generationalism. St Leonards: Allen \& Unwin.

Denzin, K. and Lincoln, Y. eds. 1994. Handbook of qualitative Research. London: Sage.

Education (General Provisions) Amendment Act No 64. 1996. Brisbane: QLD Govt Printer.

Foucault, M. 1977a. Discipline and Punish. Harmondsworth: Penguin. 1977b. Intellectuals and Power: A conversation between Michel Foucault and Gilles Deleuze. In Language Counter-Memory, Practice: Selected Essays and Interviews, ed. D. Bouchard, trans. D. Bouchard and S. Simon, 205-217. New York: Cornell University Press. . 1980. Power/Knowledge: Selected Interviews and other Writings 19721977. New York: Pantheon.

Freire, P. 1970. Pedagogy of the Oppressed. New York: Herder and Herder. 1976. Literacy and the Possible Dream. Prospects 6, no. 1:68-71.

Freire, P. and Macedo, D. 1996. A Dialogue: Culture, Language and Race. In Breaking Free: The Transformative Power of Critical Pedagogy, eds. P. Leistyna, A. Woodrum, and S. Sherblom, 199-228. Cambridge, Mass.: Harvard Educational Review.

Giroux, H. 1981. Ideology, Culture and the Process of Schooling. Philadelphia: Temple University Press.

Hall, S. 1996. The Meaning of New Times. In Stuart Hall: Critical Dialogues in Cultural Studies, eds. D. Morley, and K-H. Chen, 223-237. London and New York: 
Routledge.

hooks, b. 1996. Postmodern Blackness. In The Fontana Postmodernism Reader, ed. W.

T. Anderson, 113-126. London: Fontana.

Kincheloe, J. 2004. Critical Pedagogy. New York: Peter Lang.

Lather, P. 1991a. Feminist Research in Education: Within/Against. Geelong: Deakin University Press.

1991b. Getting Smart: Feminist research and Pedagogy within the Postmodern. New York: Routledge.

Luke, A. 2006. Teaching after the Market. In Ideology, Curriculum, and the New

Sociology of Education, eds. L. Weis, C. McCarthy, and G. Dimitriadis, 115-141.

London and New York: Routledge.

Lyotard, J. 1984. The Postmodern Condition: A Report on Knowledge. Minneapolis: University of Minnesota Press.

Marginson, S. 1993. Education and Public Policy in Australia. Melbourne: Cambridge University Press.

McChesney, R. 1999. Introd. to Profit Over People: Neoliberalism and the Global Order, by Noam Chomsky. New York: Seven Stories Press.

McGregor, G. 2000. Kids who "talk back" - critically literate or disruptive youth? Journal of Adolescent \& Adult Literacy 44, no. 3: 220

McGregor, G. and Mills, M. 2006. Boys and music education: RMXing the curriculum. Pedagogy, Culture \& Society 14, no. 2: 221-233.

McLaren, P., ed. 2006. Rage and Hope: Interviews with Peter McLaren on War, Imperialism \& Critical Pedagogy. New York: Peter Lang.

Mills, M. 2000. Troubling the 'failing' boys discourse. Discourse: studies in the cultural politics of education 21: 237-246.

Moshman, D. 1999. Adolescent Psychological Development: Rationality, Morality, and Identity. London and New Jersey: Lawrence Erlbaum Associates.

Olssen, M., Codd, J. and O’Neill, A-M. 2004. Education policy: globalization, citizenship and democracy. London: Sage.

Power, M. 1999. The Audit Society, $2^{\text {nd }}$ ed. Oxford: Oxford University Press.

Ranson, S. 2007. Public accountability in the age of neo-liberal governance. In The Routledge Reader in Education Policy and Politics, eds. J. Ozga and B. Lingard, 198-219. London and New York: Routledge.

Reinharz, S. 1992. Feminist Methods in Social Research. Oxford: Oxford University Press.

Rikowski, G. 2006. Pedagogy for revolution against education for capital: a dialogue on education in capitalism today. In Rage and Hope: Interviews with Peter McLaren on War, Imperialism \& Critical Pedagogy, ed. Peter McLaren, 239-300. New York: Peter Lang.

Sadovnik, A.R., ed. 2007. Sociology of Education: A Critical Reader. New York and London: Routledge.

Scott, A., and Freeman-Moir, J., eds. 2007. The Lost Dream of Equality. Rotterdam: Sense Publishers.

Soja, E. W. 1996. Thirdspace. Oxford: Blackwell.

Weis, L., McCarthy, C. and Dimitriadis, G. 2006. Ideology, Curriculum, and the New Sociology of Ediucation: Revisiting the Work of Michael Apple. New York and London: Routledge.

White, J. and Wyn, J. 2008. Youth and Society ( ${ }^{\text {nd }}$ Ed.). Oxford: Oxford University Press. 
